\title{
TATA KELOLA PAMERAN BERBASIS PROJECT LEARNING PROGRAM STUDI DESAIN KOMUNIKASI VISUAL UNIVERSITAS DIAN NUSWANTORO
}

\author{
Khamadi $^{1}$, Agus Setiawan², Dwi Puji Prabowo ${ }^{3}$ \\ Program Studi Desain Komunikasi Visual, Universitas Dian Nuswantoro ${ }^{1,2,3}$ \\ khamadi@dsn.dinus.ac.id, agus.setiawan@dsn.dinus.ac.id,prabowo.dinus@gmail.com
}

\begin{abstract}
Cultivating exhibitions for visual communication design students is to increase the drive to create and enhance the spirit of student appreciation for the work of students to achieve quality and character in the work. The research objective is to know and understand the governance of Project Learning-based exhibits to improve the quality of learning and build a climate of appreciation for artwork among Udinus visual communication design students. The research method uses qualitative methods which are more emphasized on observation, interviews, documentation. Through the implementation of Project Learning-based exhibition governance, learning outcomes in improving quality can be achieved.
\end{abstract}

\section{Key Words: Exhibition, Management, Project Learning}

\begin{abstract}
Abstrak: Membudayakan pameran bagi mahasiswa desain komunikasi visual adalah untuk meningkatkan dorongan mencipta dan meningkatkan jiwa apresiasi mahasiswa terhadap hasil karya mahasiswa untuk mencapai mutu kualitas dan karakter dalam kekaryaan. Adapun tujuan penelitian adalah mengetahui dan memahami tata kelola pameran berbasis Project Learning dalam upaya meningkatkan kualitas pembelajaran dan membangun iklim apresiasi karya seni dikalangan mahasiswa desain komunikasi visual Udinus. Metode penelitian menggunakan metode kualitatif yang lebih ditekankan pada observasi, wawancara, dokumentasi. Melalui implementasi tata kelola pameran berbasis Project Learning, capaian pembelajaran dalam peningkatan kualitas dapat tercapai.
\end{abstract}

Kata kunci: Pameran, Tata kelola, Pembelajaran, Project Learning

Setiap aktivitas seni dan pengucapan artistik adalah bagian dari refleksi psikis manusia terhadap dunia visual dan auralnya. Aktivitas artistik yang lebih merupakan proses adaptasi psikis tak akan berlangsung tanpa adanya suatu energi kreatif (Aesijah 2000: 69). Aktivitas yang mampu mendukung timbulnya energi kreatif salah satunya adalah penyajian karya dan kegiatan apresiasi. Penyajian karya dan kegiatan apresiasi terhadap karya seni bagi kalangan mahasiswa merupakan bagian penting dalam menumbuhkan kritik, wacana, dan iklim berkarya. Kegiatan yang perlu diwadahi dalam bentuk pameran. Pameran bagian dari wujud ruang dialog antara karya dengan penikmat atau penghayat, sehingga kedudukan pameran menjadi bagian yang amat penting. Karya-karya disuguhkan kepada khalayak ramai tidak lain adalah wujud pertangungjawaban seorang pencipta /perancang.

Di sisi lain, kegiatan apresiasi karya juga mempengaruhi kemampuan seseorang dalam proses memaknai sebuah objek karya seni rupa yaitu dalam hal khusus yang dimaksudkan adalah desain. Metode-metode perlu dikembangkan guna mencapai kualitas pemahaman dan pemaknaan sebuah desain dan karya seni pada umumnya. Sehingga karya yang diciptakan memiliki dasar konsep yang matang dan kualitas estetik yang mampu meningkatkan pemahaman makna serta taraf hidup manusia yang bermartabat. Metode yang bersinggungan dengan medan penciptaan dan 
Khamadi, Agus Setiawan, Dwi Puji Prabowo

TATA KELOLA PAMERAN BERBASIS PROJECT LEARNING

PROGRAM STUDI DESAIN KOMUNIKASI VISUAL

UNIVERSITAS DIAN NUSWANTORO

penghayatan yaitu melalui pameran

Pameran adalah media yang dapat memenuhi sifat kodrati manusia, seperti keinginan untuk melihat atau menonton, mengetahui, memperhatikan sesuatu, mendalami sesuatu, memahami atau menghayati. Dalam arti sempit, pameran adalah suatu pengaturan, penyusunan, dan penyajian benda-benda sedemikian rupa sehingga menimbulkan kesan serta pengertian tertentu bagi orang yang melihatnya. Dalam arti luas, pameran adalah suatu metode penyediaan dan penyampaian informasi yang mencakup segala aspek kegiatan yang secara sadar dan aktif dan diusahakan dalam bentuk visulisasi dan atau peragaan baik yang bersifat statis maupun dinamis sehingga menimbulkan suatu perhatian, ketertarikan, keinginan, keputusan, dan tindakan/action bagi masyarakat yang menjadi sasarannya (Widuri 2014:122).

Berangkat dari arti pameran di atas perlunya membudayakan kegiatan pameran bagi mahasiswa desain komunikasi visual. Capaian yang diharapkan diantaranya untuk memcapai kemampuan menyimak dalam artian menghayati sebuah karya, kemampuan berbicara dalam artian mampu melakukan sebuah kritik, kemampuan membaca dalam artian mampu mendiskripsikan dan pemahaman makna, kemampuan menulis dalam artian mampu mengungkapkan konsepkonsep berpikir dan interpretatif, serta kemampuan memanajemen dalam bentuk pameran.

Membudayakan pameran bagi mahasiswa desain komunikasi visual adalah untuk meningkatkan dorongan mencipta dan meningkatkan jiwa apresiasi mahasiswa terhadap hasil karya mahasiswa untuk mencapai mutu kualitas dan karakter dalam kekaryaan. Di sisi lain, mendorong iklim publikasi karya Maka, perlu digalakkan pemahaman dan aktivitas seni dalam bentuk tata kelola pameran. Bersinggungan dengan kekaryaan mahasiswa, maka budaya pameran perlu digalak melalui implementasi tata kelola atau manajemen seni.

Hasil pencermatan selama ini terhadap mahasiswa desain komunikasi visual Udinus yaitu belum sampai pada kesadaran atau belum terbentuknya iklim pameran. Karya-karya hasil ciptaannya yang sebagian besar dari pembelajaran Project Based Learning masih bersifat pemenuhan tugas yang terkumpul di meja dosen. Dorongan mencipta dan kritik belum menjadi iklim bagi mahasiswa desain komunikasi visual. Mahasiswa masih enggan menyajikan karya mereka dalam bentuk pameran. Tidak pungkiri bahwa belum terbentuknya iklim pameran berdampak pada ketidaktahuan bagaimana mahasiswa dalam mempertanggungjawabkan atas karya yang mereka ciptakan. Di sisi lain, mahasiswa masih awam bagaimana tata kelola pameran. Serangkaian kegiatan dalam upaya penyajian karya perlu dikelola dengan baik dan benar. Karya tidak cukup hanya dipajang dan disaksikan dalam kurun waktu yang terbatas. Keberadaan karya dalam kurun waktu penyajian yang terbatas harus mampu memancing budaya membaca dan menulis, serta terciptanya ruang dialog yang saling mengisi. Karya-karya yang tersaji perlu mendapat apresiasi dan memicu pembicaraan tentang konsep dan ruang kreativitas.

Beberapa aspek belum terbentuknya iklim berkarya dan berapresiasi di kalangan mahasiswa yaitu pertama kegiatan pameran terlihat sebatas seremoni dan pemajangan karya dalam kurun waktu terbatas, belum termanifestasikan dalam wujud pertanggungjawaban secara menyeluruh. Karya-karya yang disajikan belum terpublikasi dengan baik melalui katalog pameran baik secara digital maupun cetak. Di sisi lain, karyakarya terbaik belum terjamah yang sebenarnya dapat dioptimalkan sebagai referensi visual dan bahan tulisan serta pijakan dalam perancangan karya yang berkelanjutan. Perpijak dari beberapa aspek yang diuraikan di atas perlunya implementasi tata kelola pameran berkonsep dan terencana sehingga penelitian ini berupaya mengembangkan sebuah tata kelola pameran untuk penyediaan media apresiasi karya seni mahasiswa desain komunikasi visual Udinus untuk meningkatkan iklim dan kualitas keilmuan dalam bidang desain komunikasi visual.

Solusi yang dicapai adalah terselenggaranya sebuah pameran dengan mempertimbangkan tata kelola atau 
manajemen

Penyelenggaraan pameran ini dengan mempertimbangkan aspek kuratorial dan publikasi karya sebagai bentuk pertanggungjawaban kekaryaan. Terkait publikasi kekaryaan diciptakan sebuah katalog pameran berbasis online atau e-katalog.

\section{METODE}

Penelitian ini menerapkan metode kualitatif untuk mendiskripsikan tata kelola pameran dengan tahapan pengambilan data dari sumber data yang sudah ditentukan. Metode kualitatif merupakan proses penelitian dan pemahaman dengan melibatkan diri yang berdasarkan pada metode yang menyelidiki suatu fenomena sosial dan masalah manusia. Pendekatan akan menghasilkan suatu gambaran permasalahan dengan meneliti katakata, laporan terinci dari pandangan informan atau narasumber, dan melakukan studi pada situasi yang alami (Creswell 1998, 2016) Penelitian ini akan menghasilkan data deskriptif permasalahan yang diangkat.

Sehingga dapat dilihat secara garis besar bagan penelitian secara utuh dalam pentahapannya dalam tabel di bawah ini:

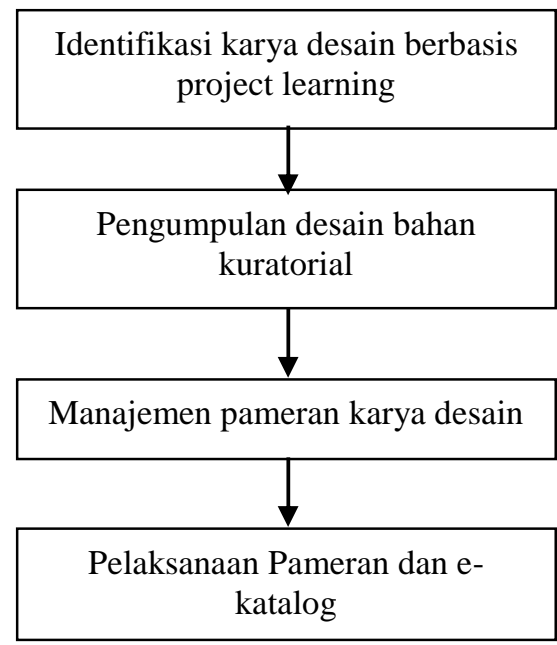

Gambar 1. Alur dan Tahap Penelitian

\section{HASIL}

\section{Pamungkas sebagai Pameran Hasil} Pembelajaran Berbasis Proyek

Sebagaimana konsep project based learning, pameran dibuat sebagai evaluasi hasil pembelajaran juga sebagai sarana apresiasi yaitu pameran tersebut diadakan berfungsi untuk mengeluarkan ide gagasan mahasiswa sebagai desainer untuk kemudian para pengunjung memberikan apresiasi atau memberi penilaian terhadap karya seni yang mereka buat. Pameran yang dibuat bertajuk Pamungkas yaitu akronim dari Pameran Unggulan Karya Akhir Semester. Sesuai akronimnya pameran ini ditujukan untuk memajang karya tugas akhir semester mahasiswa yang dinilai unggul.

Pameran ini dibuat agar dapat menumbuhkan dan menambah kemampuan apresiasi terhadap desain baik untuk penonton maupun mahasiswa sebagai desainer. Selain itu melalui pameran ini dapat melatih diri untuk dapat bekerjasama dengan orang lain. Kerjasama ini terbentuk dari keikutsertaan mahasiswa dalam kepanitiaan pameran. Kepanitian pameran dari mahasiswa ini terdiri dari ketua kelas masing-masing mata kuliah. Masing-masing ketua kelas saling berkoordinasi mulai dari persiapan, pelaksanaan, hingga evaluasi pameran.

Melalui pameran ini juga dapat melatih sikap tanggung jawab dan mandiri mahasiswa. Mahasiswa diminta untuk mempersiapkan dan menghasilkan karya secara mandiri dan penuh tanggung jawab dengan tidak melanggar hak cipta. Karya didisplay untuk diperlihatkan secara publik. Sehingga jika ada pelanggaran hak cipta pada karya, dapat berakibat buruk bagi desainer. Pameran juga ditujukan untuk menumbuhkan motivasi berkarya mahasiswa. Hal ini karena karya yang dipajang harus dikurasi untuk dipilih karya terbaik yang unggul sesuai konsep pameran Pamungkas.

Pameran ini juga memperhatikan beberapa prinsip yaitu

1. Prinsip Interaksi, yaitu prinsip yang harus berorientasi pada kepentingan penyelenggara dan pengunjung dalam penyelenggaraan pameran. Sebagaimana tujuan pameran ini diadakan yaitu memberikan apresiasi terhadap karya mahasiswa dan juga memberikan referensi bagi penonton pameran yaitu mahasiswa desain komunikasi secara luas tentang karya-karya desain yang baik. Hal ini tentunya menambah pengalaman dan pengetahuan penonton terkait standar karya yang baik, juga dapat memicu mahasiswa 
Khamadi, Agus Setiawan, Dwi Puji Prabowo

TATA KELOLA PAMERAN BERBASIS PROJECT LEARNING

PROGRAM STUDI DESAIN KOMUNIKASI VISUAL

UNIVERSITAS DIAN NUSWANTORO

lain untuk dapat berkarya lebih baik agar kedepan karyanya dapat dipajang sebagai karya terbaik pula.

2. Prinsip inisiatif, yaitu penyelenggaraan pameran yang mengambil inisiatif serta menentukan langkah-langkah yang sistematis dan terencana ke arah pendekatan khalayak ramai pada pameran yang sedang diselenggarakan.

Pengorganisasian pameran dijabarkan lebih detail pada manajemen pameran.

3. Prinsip repetisi, yaitu prinsip penyelenggaraan pameran yang dilakukan secara berulang-ulang. Prinsip ini terpenuhi dengan adanya penyelenggaraan pameran yang rutin setiap akhir semester.

4. Prinsip integritas, yaitu prinsip penyelenggaraan yang menampilkan banyak koleksi pameran. Sebagaimana jenis pameran Pamungkas yaitu pameran heterogen dengan menampilkan berbagai jenis karya desain sesuai dari hasil akhir pencapaian pembelajaran masing-masing mata kuliah seperti karya Menggambar, karya ilustrasi, hingga karya multimedia dan audio visual.

5. Prinsip efisiensi, yaitu penyelenggaraan pameran dengan melakukan penulisan secara sistematis agar tidak merepotkan penyelenggara dan pengunjung. Prinsip ini dilakukan pada pelabelan karya yang ringkas tetapi jelas.

\section{Karya Tugas Akhir Semester sebagai Karya Pameran}

Sebagaimana yang diungkapkan oleh Baysha dan Astuti (2016) bahwa Project Based Learning merupakan metoda pembelajaran yang menggunakan proyek/kegiatan sebagai media, hal ini sangat sesuai dengan pendekatan pembelajaran di desain komunikasi visual yang mengedepankan karya sebagai perwujudan akhir hasil proses kreasi visual. Sebagian besar mata kuliah di program studi Desain Komunikasi Visual berupa mata kuliah praktek dan praktikum, dimana selain dituntut pemahaman dan pengetahuan, mahasiswa juga harus mampu melahirkan ide yang solutif dari masalah atau tugas berupa karya desain yang komunikatif. Sejalan dengan pemahaman ini, maka konteks pameran sebagai kegiatan untuk mengkomunikasikan suatu produk atau karya yang berupa karya mahasiswa dengan tujuan sebagai apresiasi karya.

Capaian pembelajaran mahasiswa dalam satu semester idealnya dapat diukur secara maksimal dari hasil ujian akhir semester. Dalam konteks produk karya sebagai tugas ujian akhir semester mata kuliah praktek dan praktikum, maka kualitas kekaryaan mahasiswa idealnya dapat tercermin dari karya tugas akhir semester tersebut. Karya tugas akhir semester merupakan hasil dari pemahaman, pengetahuan, dan kemampuan yang didapat dan dimiliki mahasiswa selama satu semester. Selama ini karya tugas akhir hanya diapresiasi dalam bentuk nilai mata kuliah dari dosen pengampu. Hal ini dirasa kurang sesuai dengan teknik penilaian dalam Project Based Learning yang hanya mengedepankan penilaian analitik yaitu dosen sebatas menilai hasil produk berdasarkan kriteria yang diberikan. Sehingga diperlukan penilaian secara holistik untuk mendapatkan kesan dari karya yang dihasilkan yaitu berupa ketersampaian pesan dan kemampuan memecahkan masalah. Hal ini dikarenakan tidak sedikit terdapat karya desain yang tidak harus memenuhi semua kriteria tertentu untuk dapat menyampaikan pesan dan dapat dipahami oleh penonton.

Peran dosen pengampu menjadi sangat penting untuk memacu dan memberikan motivasi kepada mahasiswa untuk dapat menghasilkan karya tugas akhir yang terbaik. Dalam konteks pembelajaran berbasis proyek, dosen berperan sebagai fasilitator, pelatih, penasehat dan perantara untuk mendapatkan hasil yang optimal sesuai dengan daya imajinasi, kreasi dan inovasi dari mahasiswa

Melalui apresiasi karya tugas akhir lewat pameran selain memberikan apresiasi yang lebih terhadap tugas mahasiswa juga memberikan motivasi kepada mahasiswa untuk menunjukkan kemampuan terbaiknya dalam berkarya. Hal ini dikarenakan tidak semua karya mahasiswa dapat ditampilkan di pameran melainkan melalui proses kuratorial yang mengeliminasi karya-karya yang dirasa kurang. Lewat apresiasi pameran ini juga mendorong standarisasi teknis ukuran karya yang harus dibuat mahasiswa. Sebagai contoh 
jika sebelumnya karya tugas mata kuliah menggambar 1 dibuat dalam ukuran A3 maka dengan pameran ini juga dapat merubah spesifikasi teknis penugasan dengan karya dibuat dalam ukuran A2 sebagai contoh. Atau bukan dengan mengganti ukuran karya tetapi memberikan syarat tambahan tugas yaitu memberikan frame pada karya sesuai kebutuhan display pameran nantinya. Hal ini tentunya disesuaikan konsep pameran yang dilaksanakan di akhir semester.

Pembelajaran berbasis proyek ini juga mempertimbangkan kebermanfaatan karya yang dihasilkan. Sebagai contoh pada mata kuliah Tipografi Aplikatif, karya tugas akhir yang dibuat dalam bentuk produk yang dapat dipasarkan. Media pengaplikasian tipografi tidak lagi media konvensional pembelajaran tetapi diaplikasikan pada media-media yang dapat memberikan benefit atau dapat dipasarkan. Hal ini sesuai dengan visi program studi Desain Komunikasi Visual untuk membentuk jiwa kewirausahaan mahasiswanya. Berikut adalah contoh karya tugas Tipografi Aplikatif yang telah diimplementasikan pada media talenan yang saat ini sedang disukai masyarakat sebagai interior atau hiasan ruangan.

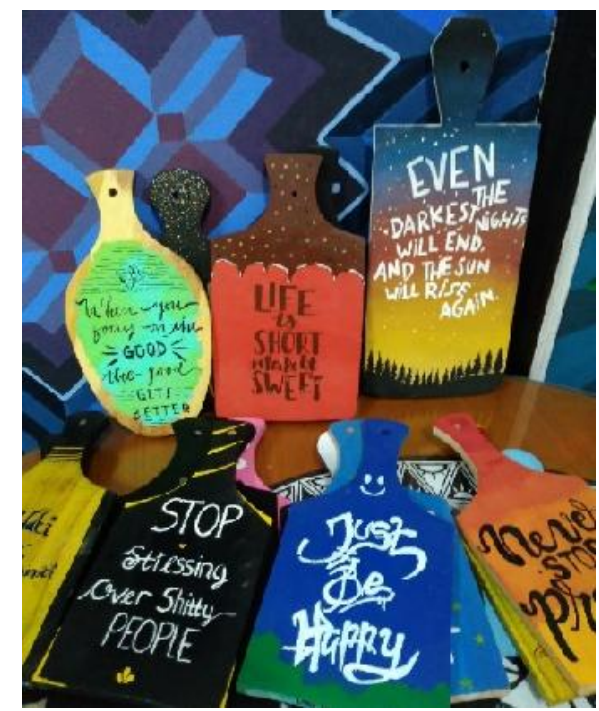

Gambar 2 Karya tugas akhir mata kuliah Tipografi Aplikatif yang berbasis proyek

\section{Kurasi sebagai Proses Evaluasi Karya Mahasiswa}

Kurasi merupakan kerja atau kegiatan yang berhubungan dengan memelihara dan menjaga serta mengawasi sebuah kegiatan pameran. Dasar-dasar dari kurasi pameran yang dapat mencerminkan kondisi situasi, visi dan misi serta citra yang dibangun dalam pameran. Salah satu proses dalam kurasi adalah mengevaluasi kelayakan dan nilai sebuah karya. Kurasi pada karya tugas akhir semester mahasiswa desain komunikasi visual ini dilakukan untuk menyeleksi karya-karya yang bisa ditampilkan sesuai kriteria yang sudah ditetapkan. Karya-karya dengan penilaian baik dari dosen pengampu akan dikurasi oleh kurator. Hal ini ditujukan untuk memudahkan proses kurasi dimana karya tugas akhir mahasiswa yang berjumlah ratusan dari masing-masing mata kuliah praktek. Kriteria penilaian yang baik ini didasarkan pada nilai angka dari karya tersebut yaitu karya yang mendapatkan nilai $B$ hingga nilai $A$. Selanjutnya karya disampaikan kepada kurator untuk dapat dinilai kelayakan.

Kurator dalam pameran seni rupa memiliki tugas untuk menjaga, mengumpulkan, menata, bahkan menentukan karya-karya yang boleh ditampilkan dalam museum atau pameran seni, selain itu kurator bekerja ibarat seorang produser sekaligus sutradara. Seniman bisa saja membuat karya yang menurut dia hebat. Tapi jika Kurator tidak menginginkan karya itu dalam pameran, maka karya itu tidak ditampilkan. Jika biasanya dalam sebuah pameran cukup menggunakan satu kurator, tetapi pada pameran ini yang bertujuan untuk memberi apresiasi terhadap karya mahasiswa yang jumlahnya sangat banyak dan heterogen maka digunakan peran koordinator mata kuliah dibawah koordinasi bidang kajian menjadi kurator.

Pemilihan karya melalui proses evaluasi yang didasarkan pada tema dan tujuan pameran yang diadakan yaitu pameran unggulan karya akhir semester atau disingkat Pamungkas. Karya yang benar-benar unggul dari segi kualitas dalam penyampaian pesan dan estetis menjadi prioritas karya yang dipamerkan. Penilaian karya sebagai bentuk evaluasi karya ini merupakan penilaian holistik yang mengedepankan bagaimana kemampuan karya dapat berkomunikasi dengan penonton nantinya. Kriteria penilaian dalam ujian akhir semester yang biasa menggunakan penilaian analitik bisa saja tidak menjadi patokan evaluasi karya oleh kurator. Hal ini karena kurator harus mempertimbangkan aspek 
Khamadi, Agus Setiawan, Dwi Puji Prabowo

TATA KELOLA PAMERAN BERBASIS PROJECT LEARNING

PROGRAM STUDI DESAIN KOMUNIKASI VISUAL

UNIVERSITAS DIAN NUSWANTORO

konseptual dan aspek teknik artistik dari karya.

\section{Manajemen Pameran dalam Pembelajaran Apresiasi Karya}

Manajemen secara umum adalah suatu proses atau kerangka kerja yang melibatkan bimbingan atau pengarahan suatu kelompok orang ke arah dan tujuan-tujuan organisasional atau maksud-maksud tertentu. Manajemen menjadi sarana untuk membantu mencapai tujuan pameran secara efektif dan efisien. Efektif berarti menghasilkan dan memamerkan karya yang unggul sesuai dengan tujuan pameran. Efisien berarti menggunakan sumber daya manusia secara rasional dan hemat, tak ada pemborosan atau penyimpangan. Karena pada dasarnya manajemen adalah cara memanfaatkan input untuk menghasilkan karya seni melalui suatu proses perencanaan, pengorganisasian, pengarahan, dan pengendalian, dengan memperhatikan situasi dan kondisi lingkungan yang ada. Manajemen pelaksanaan pameran Pamungkas ini meliputi

1. Proses berkarya. Seperti yang telah dijelaskan sebelumnya, proses berkarya disini dibuat mahasiswa melalui pembelajaran selama satu semester masingmasing mata kuliah praktek dengan pembelajaran berbasis proyek.

2. Konsep Kurasi. Konsep kurasi juga telah dijabarkan pada poin sebelumnya yaitu kurasi dilakukan oleh koordinator mata kuliah sebagai kurator. Karya-karya dengan nilai $\mathrm{B}$ hingga $\mathrm{A}$ menjadi prioritas karya yang dikurasi.

3. Tema kegiatan pameran. Pamungkas sebagai pameran yang dilakukan setiap akhir semester mengedepankan karyakarya yang unggul dari setiap mata kuliah praktek dan praktikum. Pameran kali ini mengambil tema yang senada dengan akronim Pamungkas yaitu Perfection yang berarti kesempurnaan dalam berkarya. Hal ini untuk menekankan bahwa karya yang sempurna atau unggul itu adalah karya yang diselesaikan. Selama ini tidak sedikit mahasiswa dalam berkarya jika menemui kesulitan dalam menghasilkan sebuah karya dengan mudahnya mereka berhenti atau beralih ke karya lain tanpa menyelesaikan apa yang telah mereka mulai. Hal ini menjadi keprihatinan bagi seorang desainer karena minimnya rasa tanggung jawab dan rasa percaya diri yang dimiliki. Tema ini lahir karena pada dasarnya pameran mempunyai suatu tujuan komunikasi, dimana tujuan tersebut adalah bukan sekedar diketahui umum, akan tetapi menggerakan masyarakat untuk melaksanakan suatu tindakan yang diinginkan oleh pihak yang mengadakan pameran tersebut (Widuri 2014:123).

4. Persuratan. Persuratan meliputi surat yang dibutuhkan seperti peminjaman ruang pameran, surat permohonan kurator, surat undangan pembukaan pameran, surat untuk peliputan media, dan lain sebagainya.

5. Kepanitiaan. Panitia yang dibentuk dalam pameran ini hanya melibatkan kepanitian internal dalam program studi Desain Komunikasi Visual meliputi pejabat prodi, koordinator bidang kajian, koordinator mata kuliah, dan mahasiswa yang diwakili oleh asisten laboratorium dan ketua kelas masing-masing mata kuliah praktek dan praktikum.

6. Publikasi. Publikasi dilakukan melalui media konvensional berupa poster dan media sosial di Instagram, Whatsapp, dan Line. Sebagaimana tujuan pameran sebagai media apresiasi karya akhir semester mahasiswa, maka penonton sasaran disini masih seputar lingkungan internal di Kampus Universitas Dian Nuswantoro. Publikasi juga menggandeng grup kemahasiswaan yang dimiliki oleh program studi yaitu Himpunan Mahasiswa Desain Komunikasi Visual Universitas Dian Nuswantoro.

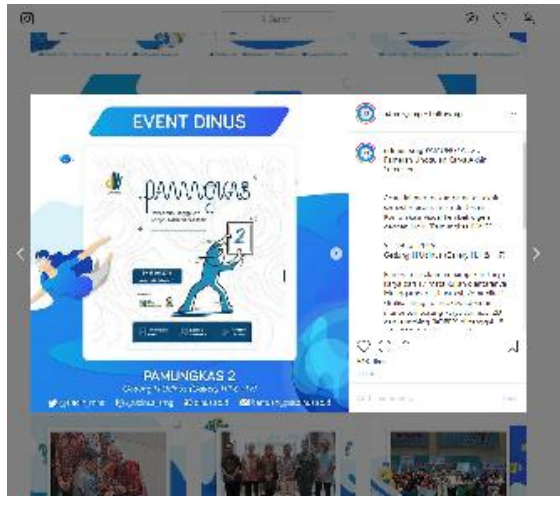

Gambar 3. Publikasi pameran di media sosial 
7. Anggaran. Anggaran dalam pameran ini bersumber dari hibah penelitian internal dan ditujukan untuk pengeluaran dari persiapan, pelaksanaan, hingga evaluasi pameran.

8. Display dan penataan ruang pameran. Display memiliki arti pamer, peragaan, pertunjukan (memperlihatkan), sedangkan feminologi desain interior display berarti suatu sistem penataan objek tertentu, apabila kata display diberi awalan (prefix) dan akhiran (suffix), maka display dapat disimpulkan sebagai sistem penataan pada ruang pamer. Display pameran dapat mencapai suatu perancangan dan memenuhi suatu persyaratan kebutuhan berdasarkan atas fungsi, kenyamanan, keamanan, kemampuan, dan estetika. Pada pameran Pamungkas menggunakan karakter display divider yaitu adanya partisi yang digunakan sebagai penyekat dan memajang karya. Display ini memudahkan penempatan posisi dan pengaturan alur sirkulasi ruangan.

9. Pelaksanaan Pameran. Pameran dilaksanakan selama 2 minggu dari tanggal 9 Juli 2019 hingga 19 Juli 2019. Adapun acara pameran terdiri dari display karya dari 13 mata kuliah praktek dan praktikum, dan adanya talk show. Pemajangan karya 13 mata kuliah dilakukan dengan pergantian karya setiap 3 hari. Hal ini dikarenakan terbatasnya ruang galeri untuk memajang seluruh karya pameran dalam satu kali pemajangan.

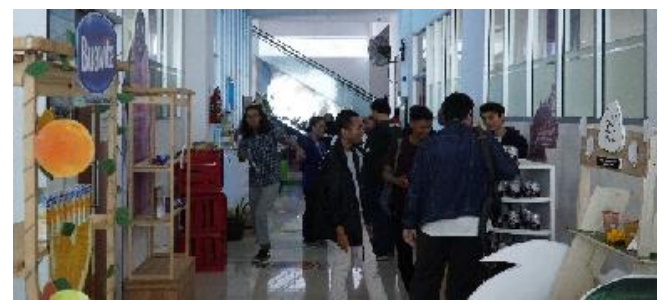

Gambar 4 Pameran juga memanfaatkan selasar untuk display karya

Talkshow diadakan berbarengan dengan apresiasi terhadap karya akhir mata kuliah Animasi 2D. Talkshow mengambil tema senada dengan apresiasi tersebut yaitu Seluk Beluk Dunia Industri Animasi.

10. Evaluasi. Proses evaluasi dilakukan setelah pameran selesai. Evaluasi dilakukan oleh seluruh panitia untuk mendapatkan review terhadap pelaksanaan pameran sehingga menjadi dasar pengembangan yang dapat dilakukan pada pameran selanjutnya.

\section{KESIMPULAN}

Tata kelola pameran Pamungkas mengedepankan tujuan untuk mengapresiasi karya mahasiswa yang dihasilkan selama proses pembelajaran berbasis proyek dalam satu semester melalui mata kuliah praktek dan praktikum. Konsep pembelajaran berbasis proyek ini sebenarnya bukan hal yang baru di metode pembelajaran yang dilakukan di mata kuliah praktek dan praktikum DKV. Namun dalam tata kelola pameran pamungkas, hal ini menjadikan standarisasi bagi karya yang harus dibuat mahasiswa. Standarisasi ini bukan hanya di aspek proses dan hasil karya yang diharapkan tetapi juga aspek teknis dan tata artistik karya yang harus dihasilkan mahasiswa.

Manajemen pameran Pamungkas menggunakan standar pameran yang baik walaupun ada beberapa aspek yang belum dimaksimalkan seperti manajemen waktu pameran yang harus mempertimbangkan ketercapaian hasil karya masing-masing mata kuliah yang tidak sama. Selanjutnya manajemen sumber daya khususnya kepanitiaan. Kurasi yang dilakukan dari pihak dosen dan panitia dari mahasiswa masih minim dari pengalaman dalam pameran. Hal ini memberikan effort yang lebih dalam pembelajaran pameran tetapi menjadi pengalaman bagi mahasiswa untuk dapat berkembang.

\section{DAFTAR PUSTAKA}

Aesijah, Siti. 2000. "Latar Belakang Penciptaan Seni (Background Of Creative Art)." Harmonia: Jurnal Pengetahuan Dan Pemikiran Seni 1(2):62-74.

Baysha, Husein and Endah Resnandari Puji Astuti. 2016. "Implementasi Pameran Fotografi Berbasis Project Based Learning Program Studi Teknologi Pendidikan Di Mataram." Jurnal Teknologi Pendidikan : Jurnal Penelitian Dan Pengembangan Pembelajaran 1(2):40-51.

Creswell, J. W. 1998. Qualitatif Inquiry and 
Khamadi, Agus Setiawan, Dwi Puji Prabowo

TATA KELOLA PAMERAN BERBASIS PROJECT LEARNING

PROGRAM STUDI DESAIN KOMUNIKASI VISUAL

UNIVERSITAS DIAN NUSWANTORO

Research Design. California: Sage Publication, inc.

Creswell, John W. 2016. Research Design: Pendekatan Metode Kualitatif, Kuantitatif, Dan Campuran. keempat. Yogyakarta: Pustaka Pelajar.

Gunawan, Topan Indraseni. 2017. "Pengembangan Strategi Tata Kelola Museum Omahku Memoriku." JURNAL TATA KELOLA SENI 2(1):54-63.

Indratmo, Effy and Tri Lestyo Handayani. 2016. "Studi Manajemen Penyelenggaraan Pameran Seni Rupa Di Bentara Budaya Yogyakarta." Brikolase : Jurnal Kajian Teori, Praktik Dan Wacana Seni Budaya Rupa 6(1).

Rais, Muh. 2010. "Model Project BasedLearning Sebagai Upaya Meningkatkan Prestasi Akademik Mahasiswa." Jurnal Pendidikan Dan Pengajaran 43(3):24652.

Widuri, Noorika Retno. 2014. "Pameran, Media Komunikasi Antara Perpustakaan Dengan Pengguna." BACA: JURNAL DOKUMENTASI DAN INFORMASI 28(2):120-26. 